\title{
PROPOSAL, ANALYSIS AND EXPERIMENTAL VERIFICATION OF NONISOLATED DC-DC CONVERTERS CONCEIVED FROM AN ACTIVE SWITCHED-CAPACITOR COMMUTATION CELL
}

\author{
Mauricio Dalla Vecchia ${ }^{1}$, Jéssika Melo de Andrade ${ }^{2}$, Neilor Colombo Dal Pont ${ }^{2}$, André Luís Kirsten ${ }^{2}$ \\ Telles Brunelli Lazzarin ${ }^{2}$ \\ ${ }^{1}$ EnergyVille, KU Leuven, Kasteelpark Arenberg 10, Heverlee, Belgium \\ ${ }^{2}$ Department of Electrical Engineering, Federal University of Santa Catarina, Florianopolis - SC, Brazil \\ e-mail: m.dallavecchia90@gmail.com; jessika.melo@inep.ufsc.br; neilorcdp@gmail.com; kirsten.andre@gmail.com \\ telles@inep.ufsc.br
}

\begin{abstract}
This paper introduces a new family of nonisolated dc-de converters that are generated by the integration of the active switched-capacitor (ASCC) and the conventional commutation cell (CCC). Based on the commutation cell concept, the new conceived hybrid active commutation cell (HACC) provides three different types of hybrid converters: buck, boost and buck-boost. All three converters are investigated in this study through the following approaches: topological stages, static gain analysis considering the switched - capacitor features, generalization of the HACC and gain for $M$ cells and steady-state analysis. The buck version presents a high conversion rate, which demonstrates that it has potential for step-down applications. To verify the proposed topologies, a prototype was built with the following specifications: $600 \mathrm{~V}$ input voltage, $150 \mathrm{~V}$ output voltage, $70 \mathrm{kHz}$ switching frequency and $1 \mathrm{~kW}$ rated power. Efficiency close to $95 \%$ was obtained at $1 \mathrm{~kW}$ for the buck topology, which demonstrates that the proposed HACC can provide gain and high efficiency at the same time.
\end{abstract}

Keywords - Active Switched-Capacitor Cell, Commutation Cell Concept, Experimental Results.

\section{INTRODUCTION}

The recent growth in the development and use of HVDC transmission systems, DC distributed systems, DC smart grids, electrical vehicles, energy storage systems, renewable sources, and telecommunication systems has enhanced the need for new solutions for dc-dc conversion. This scenario brings new applications for dc-dc converters and challenges associated with managing the energy flow in these systems.

More specifically, the current challenge in relation to dcdc conversion is to offer a high conversion ratio without isolation, for step-up or step-down applications. The isolated converters use the transformer turns ratio value to provide gain. However, the transformer is a bulky component and when a high gain is required the intrinsic parameters become significant and this offsets its benefits [1], [2]. Recently, topologies based on switched-inductor [3]-[8], switchedcapacitor [3], [6]-[14], coupled inductor [3], [15], [16],

Manuscript received 24/04/2019; first revision 29/06/2019; accepted for publication $05 / 09 / 2019$, by recommendation of Editor Marcello Mezaroba. http://dx.doi.org/10.18618/REP.2019.4.0031 impedance source circuit [3], [17], [18], series and parallel connections [19], [20], ladder [12], [14] and stacked connection [21]-[23] have provided alternative ways to obtain high gain, but all of them use a higher number of components.

The switched capacitor (SC) principle is one way to multiply or divide dc voltage. The SC converters are applied in boost topologies [10], [24], [25] as well as in buck topologies [26]. They are capable of supplying a high conversion ratio and they are magneticless topologies. Almost all the structures have good voltage stress sharing across components and, when they are properly designed, they can provide high efficiency, high power density and low weight [27]. However, the output voltage regulation is not as easy as in a conventional converter and this represents a challenge in the design of SC converters. Many authors have addressed this issue in the literature [10], [26].

On the other hand, the conventional converters present good output voltage regulation, but are not capable of providing a high conversion ratio. Hence, the integration between SC and conventional circuits could allow the combination of the advantages of the two groups of converters while overcoming the drawbacks [7], [11], [26]. This new family of converters is referred to in the literature as hybrid converters.

In general, SC cells are integrated with conventional converters to generate new topologies [7], [11], [28]-[30]. However, this concept was approached in relation to commutation cell, and a passive ladder SC cell was integrated with conventional commutation cell [11]. The new converters are analyzed through the commutation cell.

In this context, this paper proposes a hybrid active commutation cell (HACC) generated through the integration of the active switched-capacitor cell (ASCC) and the conventional commutation cell (CCC). The proposed cell generate three hybrid converters of different types: hybrid buck, hybrid boost and hybrid buck-boost. These structures present modified static gain in relation to [11] and the conventional converters. Hence, they have advantages that can be used in certain applications and thus, they can expand the range of applications of hybrid converters. A preliminary study just about buck topology was presented in [31], in which the topology was approached without considering the commutation cell principle.

The paper is divided as follows: firstly, the way in which the ASCC was integrated with the CCC is described and the 
new converters generated by this combination are presented. Subsequently, a theoretical analysis of the hybrid buck topology is shown, addressing the main characteristics of the topology. Finally, experimental results are presented to validate the proposed topologies.

\section{II. . INTEGRATION OF AN ACTIVE SWITCH CAPACITOR CELL WITH THE CONVENTIONAL DC-DC CELL}

The conventional dc-dc cell (see Figure 1.a) is employed to generate the buck, boost and buck-boost classical converters. The ladder SC cell is used to provide step-up or step-down circuits, where the gain can be increased by adding more cells in a ladder connection [32]. This implementation can use passive (diodes) or active (MOSFET, IGBT, SIC, GAN) switches. The cell proposed herein is generated connecting the CCC (Figure 1.a) and the ASCC (Figure 1.b) in a ladder configuration. To generate the proposed HACC (Figure 1.c), the terminals $n_{1}$ and $c_{1}$ of the $\mathrm{CCC}$ are connected, respectively, with the terminals $\mathrm{b}_{2}$ and $\mathrm{a}_{2}$ of the ASCC, as shown in Figures 1.a, 1.b and 1.c. The HACC employs three switches $\left(S_{1}, S_{2}\right.$ and $\left.S_{3}\right)$, one diode $\left(D_{1}\right)$, three capacitors $\left(C_{1}, C_{2}\right.$ and $\left.C_{3}\right)$ and one inductor $(L)$. The resultant cell has three terminals, labelled ' $a$ ', ' $b$ ' and 'c', in which the input dc-dc source and the output load are connected.

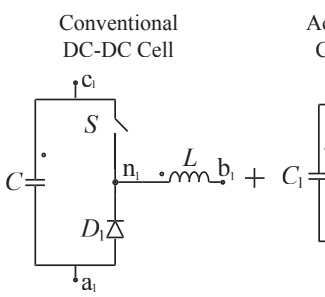

(a)
Active Switched Capacitor Cell

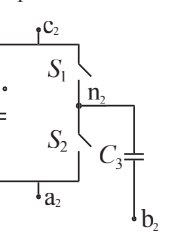

(b)

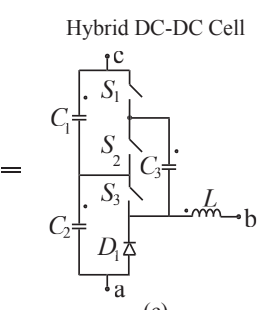

(c)
Fig. 1. (a) Conventional dc-dc cell (CCC); (b) active switchedcapacitor cell (ASCC), and; (c) hybrid dc-dc cell (HACC).

The topologies derived from the HACC have the input and output connections described in Table I. With these connections, a family of three new nonisolated dc-dc converters is generated, as is shown in Figures 2.a, 2.b and 2.c. The topologies are named as follows: hybrid dc-dc buck converter (Figure 2.a), hybrid dc-dc boost converter (Figure 2.b) and hybrid dc-dc buck-boost converter (Figure 2.c). It should be highlighted that the names buck, boost and buck-boost are used in relation to the connections between input and output stages and do not necessarily reflect the gain characteristics of the structures.

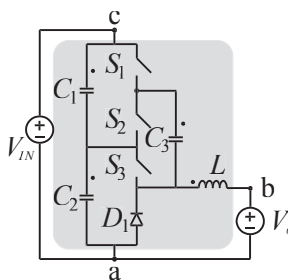

(a)

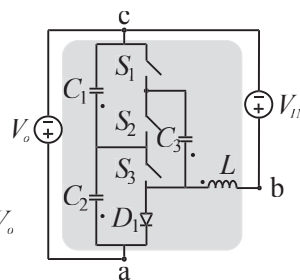

(b)

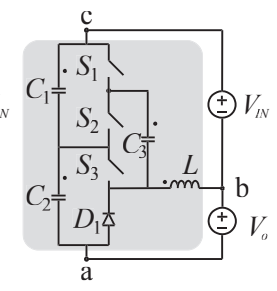

(c)
Fig. 2. (a) Hybrid dc-dc buck converter; (b) hybrid dc-dc boost converter, and; (c) hybrid dc-dc buck-boost converter.
A similar approach was proposed in [11], where a hybrid commutation cell was derived from a passive switchedcapacitor cell (implemented only with diodes). The two commutation cells are similar, with the ladder configuration and the same number of semiconductors, however, the proposed HACC uses three active and one passive switch while the commutation cell in [11] employs one active and three passive switches. Additionally, the converters generated by the integration of an active and a passive cells present different static gains, different topological stages and are suitable for different applications, as will be presented and discussed in greater detail in Section III and IV.

One of the advantages of SC circuits is that more SC cells (' $M$ ' cells) can be used to increase the conversion rate, as shown in Figure 3. This figure present the generalized hybrid dc-dc buck converter, which can provide a high step-down gain. The generalized boost and buck-boost topologies can be also obtained, following the input and output connections shown in Table I. The ladder configuration has the advantage that the voltage stress on the power components are equally divided and clamped by the switched capacitors, thus when more SC cells are added the gain will increase but the voltage stress will remain constant.

TABLE I

Connections Used to Generate the Three Proposed dc-dc Converters

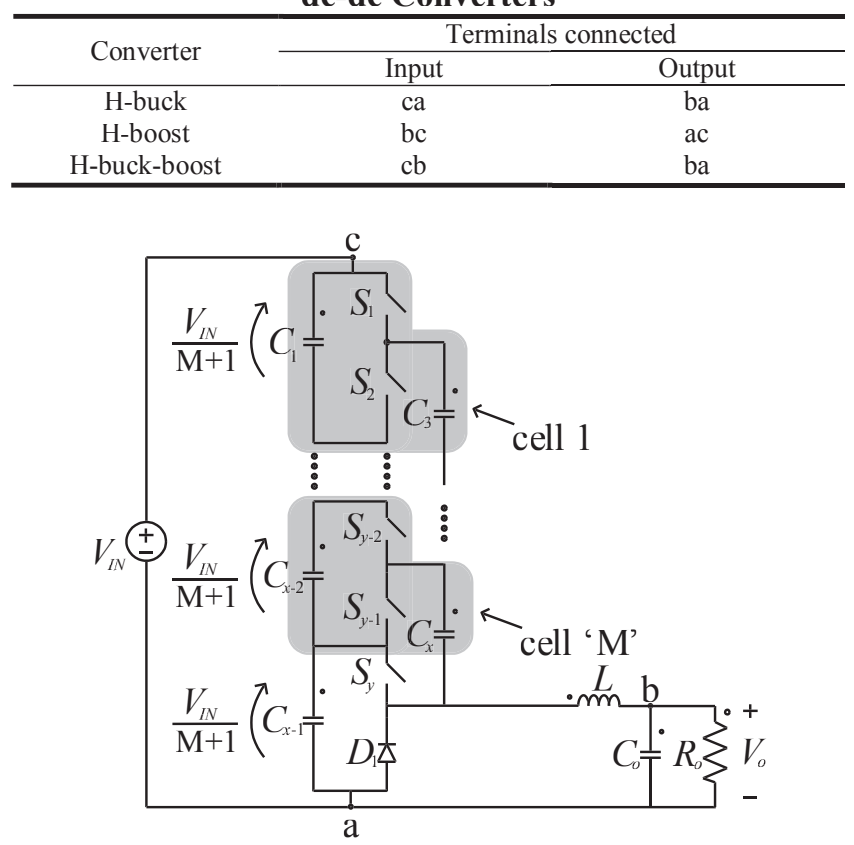

Fig. 3. Generalization of the switched-capacitor cell for the proposed hybrid dc-dc buck converter.

\section{THEORETICAL ANALYSIS OF THE BUCK TOPOLOGY}

This section presents the theoretical analysis for the buck converter (Figure 2.a), which is then extended to the boost and buck-boost topologies (Figures 2.b and 2.c). 


\section{A. Topological Stages}

The topologies presented in Figures 2.a, 2.b and 2.c have two topological stages, as shown in Figure 4 and detailed below:

- First Topological Stage: the PWM1 signal turns on $S_{1}$ and $S_{3}$, while PWM 2 (complementary to the PWM1 signal) turns off $S_{2}$. With this driving command, capacitors $C_{1}$ and $C_{3}$ are parallel connected and both capacitors charge, while capacitor $C_{2}$ discharges. In this topological stage, the inductor stores energy. The equations extracted from this stage are given in (1). The equivalent series resistance of the capacitors $\left(r_{C}\right)$ was considered during the analysis.

- Second Topological Stage: the PWM2 signal drives switch $S_{2}$, which turns on it, while PWM 1 turns off $S_{1}$ and $S_{3}$. Capacitor $C_{3}$ starts to discharge and hence diode $D_{1}$ is forward biased. The capacitor $C_{1}$ discharges, capacitor $C_{2}$ charges and the inductor provides energy to the load. The equations extracted from this stage are given in (2).
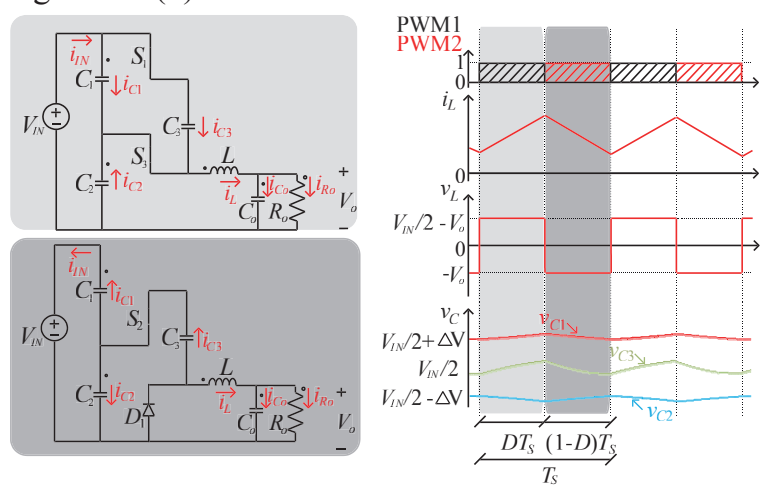

Fig. 4. Hybrid dc-dc buck converter: First (upper figure in light gray) and second (lower figure in dark gray) topological stages, and main waveforms for one switching period (right figure).

$$
\begin{gathered}
\left\{\begin{array}{c}
v_{L}=i_{C 2} r_{C}+v_{C 2}-v_{o} \\
V_{I N}=i_{C 1} r_{C}+v_{C 1}+i_{C 2} r_{C}+v_{C 2} \\
i_{L}=i_{C 1}+i_{C 2}+i_{C 3} \\
i_{C 1} r_{C}+v_{C 1}=i_{C 3} r_{C}+v_{C 3} \\
i_{L}=i_{C o}+i_{R o}
\end{array}\right. \\
\left\{\begin{array}{c}
v_{L}=-v_{o} \\
V_{I N}=i_{C 1} r_{C}+v_{C 1}+i_{C 2} r_{C}+v_{C 2} \\
i_{C 3}=i_{C 1}+i_{C 2} \\
i_{C 2} r_{C}+v_{C 2}=i_{C 3} r_{C}+v_{C 3} \\
i_{L}=i_{C o}+i_{R o}
\end{array}\right.
\end{gathered}
$$

It should be highlighted that there is no discontinuous conduction mode (DCM) in the proposed HACC. During the second topological stage, if the inductor current reaches zero, it will become negative, because there is a closed circuit between $C_{2}, C_{3}, \mathrm{~S}_{2}, L$ and $R_{o}$ for this current to flow. Thus, there is no DCM. The topological stages described in this section are valid for the three converters generated from the HACC.

\section{B. Switched-Capacitor Cell}

The SC cell can be modeled as an equivalent resistance $\left(R_{e q}\right)$, as shown in Figure 5, and the value of this resistance is defined in (3) [33] as a function of the switched frequency $\left(f_{s}\right)$, the duty cycle $(D)$ and the time constant ( $\tau$ ) given by (4):

$$
\begin{gathered}
R_{e q}=\frac{1}{f_{s} C_{3}} \frac{1-e^{\frac{-1}{f_{s} \tau}}}{1-e^{\frac{-D}{f_{s} \tau}}-e^{\frac{-(1-D)}{f_{s} \tau}}+e^{\frac{-1}{f_{s} \tau}},} \\
\tau=C_{3} \underbrace{\left(r_{o n}+r_{C}\right)}_{r},
\end{gathered}
$$

where, $r$ is the total conduction resistance of the multiplier cell and $r_{o n}$ is the conduction resistance of the semiconductors.

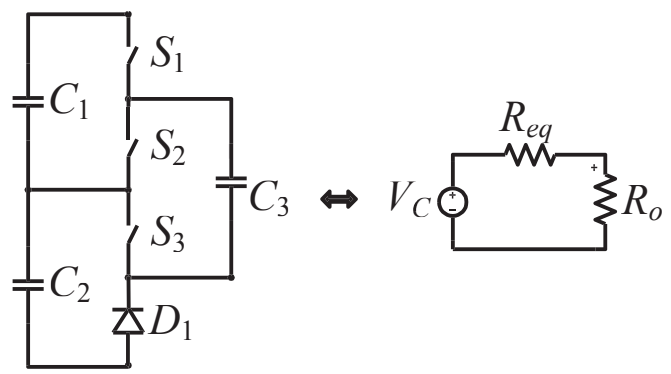

Fig. 5. Complete SC cell and equivalent circuits.

Isolating $C_{3}$ in (4) and substituting in (3), the behavior of $R_{e q}$ as a function of $f_{s} \tau$ is shown in Figure 6.a, for a fixed $D$ equal to 0.5 , which provides the maximum cell gain, as seen in Figure 7. It should be noted that the equivalent resistance value affects the mode of operation of the SC cell. There are three different modes of operation: total charge, partial charge and no charge. In total charge mode, Figure 6.b, the capacitor current has higher peak values, which will lead to greater losses. In no charge mode, Figure 6.d, there are no current peaks, however, high capacitance values are required. In the partial charge mode, Figure 6.c, the current peaks are smaller than in the total charge mode and it is not necessary to use high capacitance values. Thus, the partial charge mode provides a better cost/benefit in terms of volume and efficiency.

It should be noted that, the partial charge mode is obtained when the charging interval $\left(D T_{s}\right)$ is lower than $5 \tau$ [33]:

$$
D T_{s} \leq 5 \tau=5 r C_{3}=5\left(r_{o n}+r_{C}\right) C_{3}, .
$$

The minimum capacitance, for a fixed $D$ equal to 0.5 , is given by:

$$
C=C_{1}=C_{2}=C_{3} \geq \frac{0.1}{f_{s}\left(r_{o n}+r_{c}\right)} .
$$

The boundary between partial charge and no charge mode occurs in $f_{s} \tau$ equal to 1.44 [33]. In this point, the equivalent resistance varies less than $1 \%$, when the $f_{s} \tau$ is increased. Thus, after this point the no charge mode can be considered. Based on that point, the maximum capacitance can be calculated by:

$$
C=C_{1}=C_{2}=C_{3} \leq \frac{1.44}{f_{s}\left(r_{o n}+r_{c}\right)} .
$$

On analyzing the circuit of Figure 5, the real gain of the $\mathrm{SC}$ cell, considering the charge and discharge of the capacitors, is given by:

$$
G_{S C}=\frac{V_{R o}}{V_{C}}=\frac{R_{o}}{R_{o}+R_{e q}},
$$

and thus, the generalized gain is given by: 


$$
G_{S C M}=\frac{M R_{o}}{R_{o}+R_{e q}} .
$$

The SC cell static gain for ' $M$ ' cells is shown in Figure 7, considering $R_{o} \gg R_{e q}$ (about 100 times). It should be highlighted that the maximum gain occurs close to $D=0.5$.

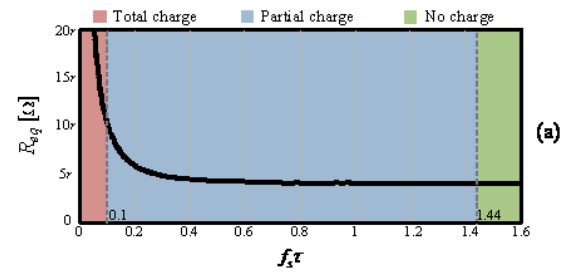

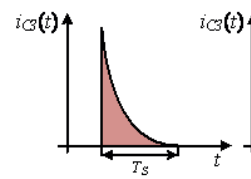

(b)

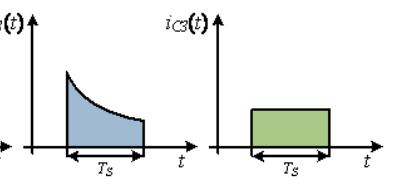

(c)

(d)
Fig. 6. SC cell behavior: (a) $R_{e q}$ as a function of $f_{s} \tau$, and with current in $C_{3}$ for (b) total charge mode, (c) partial charge mode and (d) no charge mode.

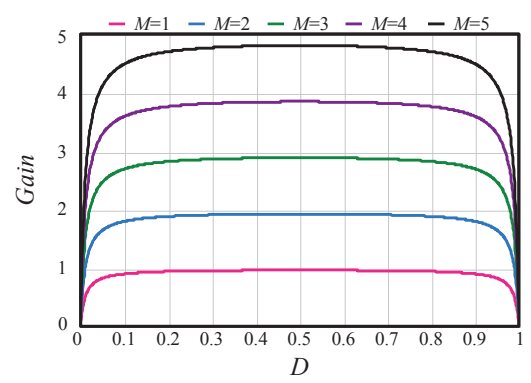

Fig. 7. Voltage gain for ' $\mathrm{M}$ ' SC cells.

\section{Static Gain of the Proposal Topologies}

The ideal static gain of the buck converter derived from HACC can be obtained from the energy balance in the inductor:

$$
v_{C 2} D-v_{o} D=v_{o}(1-D),
$$

where:

$$
v_{C 2}=\frac{V_{I N}}{M+1} .
$$

Substituting (11) in (10), the static gain of the topology as a function of the number of SC cells $(M)$ is described as:

$$
G_{\text {buck }}=\frac{v_{o}}{V_{I N}}=\frac{D}{M+1} .
$$

Similarly, the gains of the proposed hybrid boost and buck-boost converters can be given as follows:

$$
\left\{\begin{array}{l}
G_{\text {boost }}=\frac{(M+1)}{(M+1)-D} \\
G_{\text {buck_boost }}=\frac{D}{(M+1)-D}
\end{array} .\right.
$$

The static gains provided by (12) and (13) are valid for the whole operation range of these topologies, because they have no DCM. This is an important feature provided by the proposed HACC, which distinguishes it from other solutions (such as [11]).

The real static gain of the hybrid buck, boost and buckboost can be described as a function of the SC gain given by
(14). The real static gain considers the SC losses due to the charge and discharge of the capacitors, which are inherent to the principle of SC operation.

In Figures 8.a, 8.b and 8.c the ideal static gain behavior for equations (12) and (13) can be observed, considering ' $M$ ' ASCC for the buck, boost and buck-boost converter, in this order. The addition of the ASCC does not change the linear gain characteristic of the buck converter, as shown in Figure 8.a. For the boost and buck-boost topologies derived from the ASCC cell, the gain behavior is still non-linear, however it is limited, respectively, to between $1<G_{\text {boost }}<2$ and $0<G_{\text {buck-boost }}<1$.

It should be noted that the converters received the names buck, boost and buck-boost because of the input and output connections on the hybrid cell, and this does not necessarily mean that their behavior is similar with the conventional dcdc converters. For example, the buck-boost converter obtained from the hybrid dc-dc cell proposed herein only operates as a step-down converter, while the conventional buck-boost can operate as a step-down and step-up converter.

$$
\left\{\begin{array}{l}
G_{r_{\text {_buck }}}=\left(\frac{D}{M+1}\right)\left(\frac{R_{o}}{R_{o}+R_{e q}}\right) \\
G_{r_{\text {_boost }}}=\left(\frac{(M+1)}{(M+1)-D}\right)\left(\frac{R_{o}}{R_{o}+R_{e q}}\right) . \\
G_{r_{\text {_buckboost }}}=\left(\frac{D}{(M+1)-D}\right)\left(\frac{R_{o}}{R_{o}+R_{e q}}\right)
\end{array}\right.
$$

Figures 8.d, 8.e and 8.f show the static gain curve considering the real gain of the SC cell given by (14), considering $R_{o} \gg R_{e q}$ (about 100 times). When comparing the real gain curve with the ideal curve it should be highlight that for $D<0.1$ and $D>0.9$ the gain of the converters decreases.
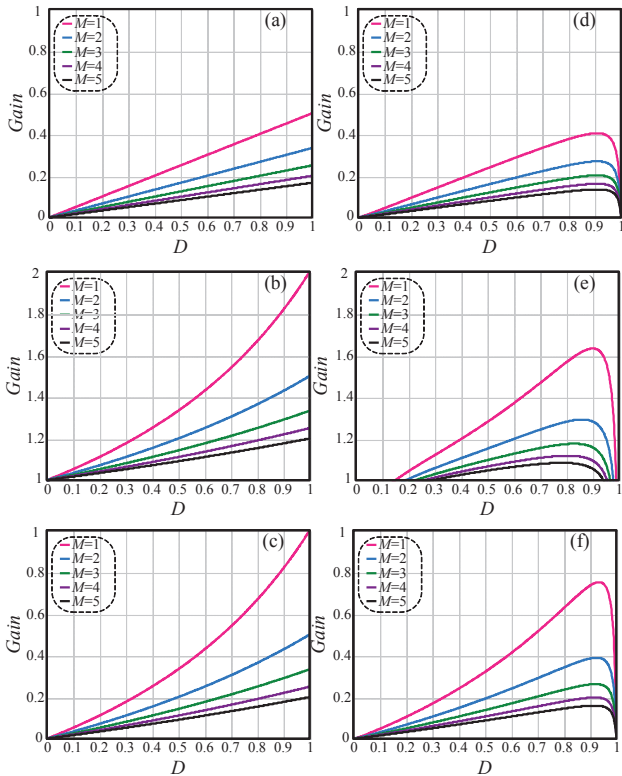

Fig 8. Static gain of the three converters derived from the hybrid dcdc cell for different numbers of SC cells: (a) buck ideal static gain; (b) boost ideal static gain; (c) buck-boost ideal static gain; (d) buck real static gain; (e) boost real static gain; and (f) buck-boost real static gain. 


\section{Steady-State Analysis}

The equations in (1) and (2) can be used to obtain the coefficients of the matrixes $A_{1}$ and $B_{1}$, for the first topological stage, and $A_{2}$ and $B_{2}$ for the second topological stage, respectively. Capacitances $C_{1}, C_{2}$ and $C_{3}$ are considered equal in this analysis, and the result is presented in Table II for the buck converter conceived from the HACC.

To be able to calculate the steady-state equations of the system, the matrixes shown in Table II are substituted in:

$$
\left\{\begin{array}{l}
A=A_{1} D+A_{2}(1-D) \\
B=B_{1} D+B_{2}(1-D)
\end{array},\right.
$$

and, after mathematical manipulations using:

$$
\dot{x}=A x+B u \stackrel{\text { steady state }}{\longrightarrow} 0=A x+B u,
$$

where $u$ is the input voltage $\left(V_{I N}\right)$ of the circuit, the steadystate equations for the inductor current and the voltage across all of the capacitors are given in (17), including and not including the ESR resistance $r_{C}$.

On analyzing the topological stages shown in Figure 4, the semiconductors from the power stage are submitted to a voltage stress equal to half of the input voltage, instead of the entire input voltage, as occurs in the conventional buck converter. This feature is confirmed by theoretical steadystate analysis described by:

$$
\left(\begin{array}{l}
I_{L} \\
V_{C 1} \\
V_{C 2} \\
V_{C 3} \\
V_{C o}
\end{array}\right)=\left(\begin{array}{c}
\frac{4 V_{I N} D(1-D)}{8(1-D) R_{o}+3 D r_{C}} \\
\frac{V_{I N}\left[4(1-D) R_{o}+D r_{C}(D+2)\right]}{8(1-D) R_{o}+3 D r_{C}} \\
\frac{(1-D) V_{I N}\left(4 R_{o}+D r_{C}\right)}{8(1-D) R_{o}+3 D r} \\
\frac{V_{I N}\left[4(1-D) R_{o}+D r_{C}(2 D+1)\right]}{8(1-D) R_{o}+3 D r} \\
\frac{4 V_{I N} D R_{o}(1-D)}{8(1-D) R_{o}+3 D r}
\end{array}\right) \stackrel{r_{c}=0}{\longrightarrow}\left(\begin{array}{c}
\frac{V_{I N}}{2 R_{o}} \\
\frac{V_{I N}}{2} \\
\frac{V_{I N}}{2} \\
\frac{V_{I N}}{2} \\
\frac{V_{I N} D}{2}
\end{array}\right)
$$

It should be noted that the element $X_{51}$ of the resulting vector presented in (17) is similar to (12), which represents the gain of the buck converter in CCM, corroborating the steady-state analysis presented above. The analysis can be directly extended to the boost and buck-boost converters derived from the proposed HACC.

TABLE II

Matrix Analysis to Obtain the Steady-State Equations that Represent the Main Characteristics of the Hybrid dc-dc Buck Converter.

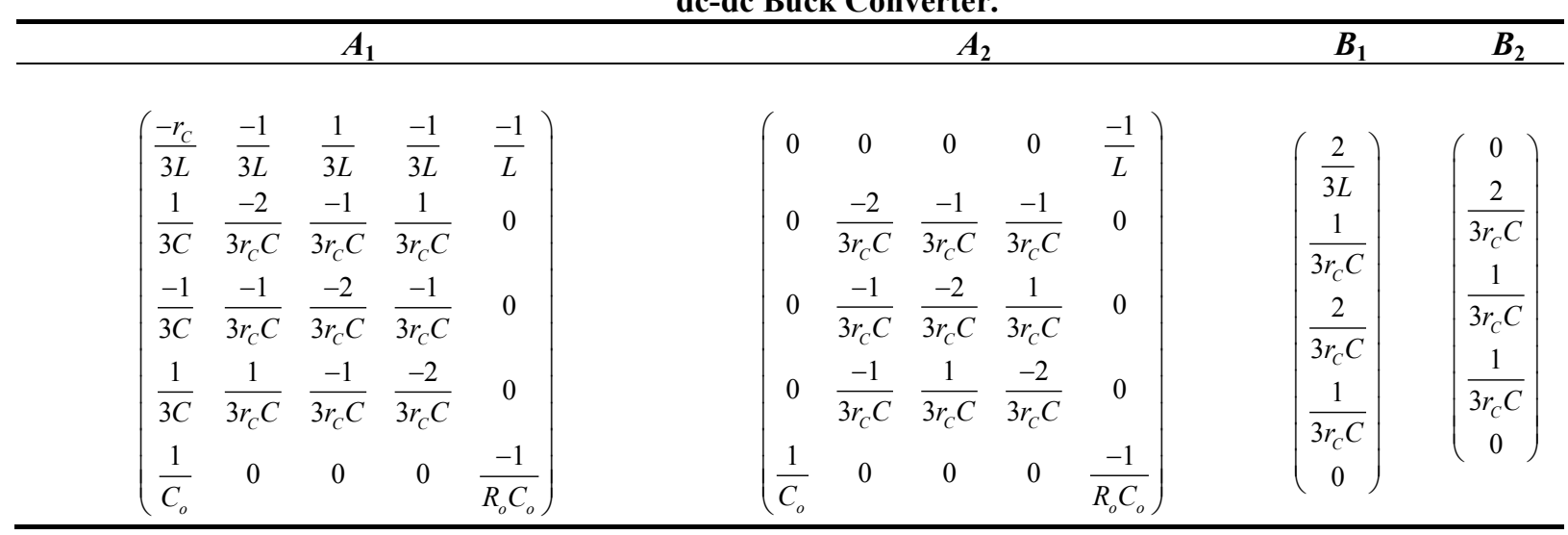
CONVERTERS AND OTHER SOLUTIONS

Table III shows a comparison of the topologies proposed herein with conventional topologies (buck, boost and buckboost), the 3-level buck converter and structures proposed in [11]. The comparison is made in relation to the static gain range, voltage stress on the power semiconductors, and number of components.

In the buck structure, the addition of one ASCC to the conventional commutation cell reduces the voltage stress on the power semiconductors to half in relation to the conventional buck converter. However, as a drawback, the new topology has two extra controllable switches and three more capacitors. The proposed buck topology presents a limited voltage gain from zero to half of the input voltage, and thus a comparison is made in Table III in relation to the 3-level buck converter [31], since both topologies present the same static gain.

The proposed boost topology can be compared to the conventional boost and buck-boost converters. The voltage gain profile of the proposed boost converter starts from unity and stops at twice, when operating with the maximum duty cycle. A similar gain is obtained either with a conventional boost topology working in a limited duty cycle range of 0 to 0.5 , or with a conventional buck-boost topology with a duty cycle range of 0.5 to 0.67 . However, despite using a greater number of components, the proposed boost topology presents a significant reduction in the stress in all power switches $\left(V_{o} / 2\right)$ and more accurate output voltage variation, as previously mentioned.

The proposed buck-boost topology is a step-down converter, which is equivalent to either the conventional buck-boost topology operating with a duty cycle range of 0 to 0.5 or the conventional buck converter. A disadvantage of the proposed buck-boost topology is the greater number of components compared to conventional converters. Nevertheless, the buck-boost converter offers lower voltage stress in all power switches $\left(\left(V_{I N}+V_{o}\right) / 2\right)$ in relation to the conventional buck-boost converter $\left(V_{I N}+V_{o}\right)$. Thus, it is suitable for high voltage applications.

\section{COMPARISON BETWEEN THE PROPOSED}


TABLE III

Qualitative and Quantitative Comparison between the Proposed Topologies and Other Converters

\begin{tabular}{|c|c|c|c|c|c|c|c|}
\hline \multirow[t]{2}{*}{ Topology } & \multirow[t]{2}{*}{ Gain } & \multirow[t]{2}{*}{$\mathrm{V}_{\mathrm{S} 1}$} & \multirow[t]{2}{*}{$\mathbf{V}_{\text {Dmax }}$} & \multicolumn{4}{|c|}{$\begin{array}{c}\text { Number } \\
\text { of }\end{array}$} \\
\hline & & & & C & $\mathbf{S}$ & D & $\mathbf{L}$ \\
\hline C-Buck ${ }^{1}$ & $\mathrm{D}$ & $V_{I N}$ & $V_{I N}$ & 1 & 1 & 1 & 1 \\
\hline $\begin{array}{c}\text { 3-Level Buck } \\
{[26]}\end{array}$ & $\begin{array}{c}\frac{D}{2} \text { to }(\mathrm{D}<0.5) \\
\frac{1+D}{2} \text { to } \\
(\mathrm{D}>0.5)\end{array}$ & $\frac{V_{L N}}{2}$ & $\frac{V_{I N}}{2}$ & 2 & 4 & 0 & 1 \\
\hline H-Buck ${ }^{2}$ & $\begin{array}{l}\frac{1+D}{2} \text { to } \\
(0 \leq D \leq 1)\end{array}$ & $\frac{V_{L N}}{2}$ & $\frac{V_{I N}}{2}$ & 3 & 1 & 3 & 1 \\
\hline H-Buck ${ }^{3}$ & $\begin{array}{c}\frac{D}{2} \text { to } \\
(0 \leq D \leq 1)\end{array}$ & $\frac{V_{I N}}{2}$ & $\frac{V_{I N}}{2}$ & 4 & 3 & 1 & 1 \\
\hline C-Boost ${ }^{1}$ & $\frac{1}{1-D}$ & $V_{v}$ & $V_{0}$ & 1 & 1 & 1 & 1 \\
\hline H-Boost ${ }^{2}$ & $\frac{2}{1-D}$ & $\frac{V_{o}}{2}$ & $\frac{V_{o}}{2}$ & 3 & 1 & 3 & 1 \\
\hline H-Boost ${ }^{3}$ & $\frac{2}{2-D}$ & $\frac{V_{o}}{2}$ & $\frac{V_{o}}{2}$ & 4 & 3 & 1 & 1 \\
\hline $\begin{array}{l}\text { C-Buck- } \\
\text { Boost }^{1}\end{array}$ & $\frac{D}{1-D}$ & $V_{I N}+V_{0}$ & $V_{I N}+V_{o}$ & 1 & 1 & 1 & 1 \\
\hline $\begin{array}{c}\text { H-Buck- } \\
\text { Boost }^{2}\end{array}$ & $\frac{1+D}{1-D}$ & $\frac{V_{I N}+V_{o}}{2}$ & $\frac{V_{I N}+V_{o}}{2}$ & 3 & 1 & 3 & 1 \\
\hline $\begin{array}{c}\text { H- Buck- } \\
\text { Boost }^{3}\end{array}$ & $\frac{D}{2-D}$ & $\frac{V_{L N}+V_{o}}{2}$ & $\frac{V_{I N}+V_{o}}{2}$ & 4 & 3 & 1 & 1 \\
\hline
\end{tabular}

On comparing the topologies proposed in this paper with those addressed in [11], it is possible to conclude that the two types of topology together reconstruct the static gain behavior of the conventional buck, boost and buck-boost converters, as can be seen in Table III. This is obtained with less effort in relation to the voltage stresses and duty cycle. Hence, when a higher conversion rate is needed, one of the topologies proposed herein or in [11] can be used. Therefore, the specification will determine which topology is more adequate. It should be noted that the HACC-based topologies present a larger number of controlled semiconductors when compared to the structures discussed in [11], however they always operate in CCM.

\section{EXPERIMENTAL RESULTS}

A prototype was designed and used to corroborate the topologies proposed in this paper, which is seen Figure 9. The prototype was built for the buck topology specification (as described in Table IV) and the components used are exposed in Table V. Using the commutation cell concept, the same prototype was also employed to verify the boost and buck-boost topologies, following the connections presented in Table I.

A. Boost Topology
To verify the hybrid boost topology (shown in Figure 2.b), an input voltage of $300 \mathrm{~V}$ was used and the duty cycle was set at 0.5 . According to (13), an output voltage of $400 \mathrm{~V}$ is expected, since the gain of the structure is $4 / 3$. Figure 10 shows $V_{v}$ and $V_{I N}$. The output voltage measurement was $403 \mathrm{~V}$, which validates the static gain of the structure. Figure 10 also shows the voltage stress of $S_{1}$, which is half of the output voltage $(200 \mathrm{~V})$. These results verify the gain of the proposed switched-capacitor cells and voltage stresses on the semiconductors.

\section{B. Buck-Boost Topology}

The buck-boost converter derived from the HACC (Figure 2.c) was verified with an input voltage of $300 \mathrm{~V}$ and duty cycle of 0.4 . The theoretical gain calculated from (13) was $1 / 4$, which provides an output voltage of $75 \mathrm{~V}$. The experimental results presented in Figure 11 show an output voltage of $79 \mathrm{~V}$, which is only $4 \mathrm{~V}$ higher than the theoretical voltage (this error of $5.33 \%$ is due to the open-loop operation of the converter).

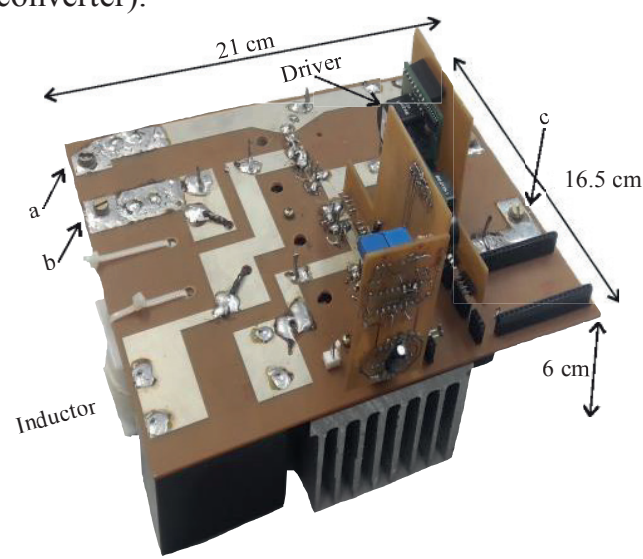

Fig. $9.1 \mathrm{~kW}$ prototype used to verify experimentally the proposed converters.

TABLE IV

Specifications of the Test Setup

\begin{tabular}{cc}
\hline Parameters & Values \\
\hline Input Voltage & $V_{I N}=600 \mathrm{~V}$ \\
Output Voltage & $V_{o}=150 \mathrm{~V}$ \\
Output Power & $P_{o}=1 \mathrm{~kW}$ \\
Switching Frequency & $f_{s}=70 \mathrm{kHz}$ \\
Nominal Duty Cycle & $D=0.5$ \\
Number of Cells & $M=1$ \\
\hline
\end{tabular}

TABLE V

Components Used in the Prototype

\begin{tabular}{cc}
\hline \multicolumn{3}{c}{ Components } \\
\hline \multicolumn{3}{c}{$535 \mu \mathrm{H}$} \\
Inductor $L$ & Core: EPCOS N87-55/28/21 \\
& Number of turns: 59 \\
& Wire: $24 \mathrm{AWG}$ \\
Switches $S_{1}, S_{2}$ and $S_{3}$ & IPx60R099C6 $-r_{\text {on }}=0.099 \Omega$ \\
& $600 \mathrm{~V} / 24 \mathrm{~A}$ \\
Diode $D_{1}$ & $\mathrm{C} 3 \mathrm{D} 10060 \mathrm{~A}$ \\
& $600 \mathrm{~V} / 10 \mathrm{~A}$ \\
Capacitors $C_{1}, C_{2}$ and $C_{3}$ & $100 \mu \mathrm{F}, r_{c}=4.7 \mathrm{~m} \Omega$ \\
& EZPE50107MTA \\
& $500 \mathrm{~V} / 10 \mathrm{~A}$ \\
\hline
\end{tabular}

C. Buck Topology 
The prototype shown in Figure 9 was developed for the hybrid buck topology. Thus, full tests were conducted in this configuration, which was designed for $1 \mathrm{~kW}$ rated power.

To verify the theoretical gain obtained from the steadystate analysis described in this paper, the buck topology was tested at three different operation points $(D=0.3, D=0.5$, $D=0.7$ ) and the experimental results are shown in Figures 12.a, 12.b and 12.c. On setting the duty cycle at $D=0.3$, the output voltage was $92 \mathrm{~V}$, as seen in Figure 12.a [theoretical value from (9) was $90 \mathrm{~V}$ ]. When the duty cycle was set at $D=0.5$, the output voltage was $154 \mathrm{~V}$, as shown in Figure $12 . b$ [theoretical value was $150 \mathrm{~V}$ ]. Finally, on setting the duty cycle at $D=0.7$, the output voltage was $210 \mathrm{~V}$, as seen in Figure 12.c (theoretical value was $210 \mathrm{~V}$ ). In all cases the voltage on the switches and capacitors are independent of the duty cycle and equal to half of the input voltage, as can be seen from the measured $V_{S 1}$ and $V_{C 1}$ values. The voltages across these components are clamped by the switched capacitor $C_{3}$. The self-balance voltages provided by the switched capacitor on $V_{C 1}$ and $V_{C 2}$ are shown in Figure 13.

For the nominal duty cycle $(D=0.5)$, load steps were performed to evaluate the regulation of the circuit from $50 \mathrm{~W}$ to $1.150 \mathrm{~kW}$, as shown in Figure 14. As expected, since the converter operates in open-loop, the output voltage drops as the output power increases. Nevertheless, the curve presents a flat drop, which means the proposed HACC does not have high losses, even when using more components compared with the conventional commutation cell.

The efficiency was also measured for the entire power range and the result is shown in Figure 15. The efficiency curve shows a flat behavior at around 95\%, above $700 \mathrm{~W}$, and it reaches a peak value of $95.5 \%$ at rated power, which enables the proposed converter to step-down voltages with high efficiency.

Figure 16.a, 16.b and 16.c show how the theoretical losses are distributed among the inductor, capacitors, diode and switches in the buck, boost and buck-boost topologies, respectively. In this analysis, the resistance in the current path $\left(r_{\text {on }}\right.$ and $\left.r_{c}\right)$ is considered. The largest losses occurs in the buck-boost topology, which provided a theoretical efficiency of $87.74 \%$ at rated power. The inductor and diode are responsible for $40 \%$ of the total losses. The boost

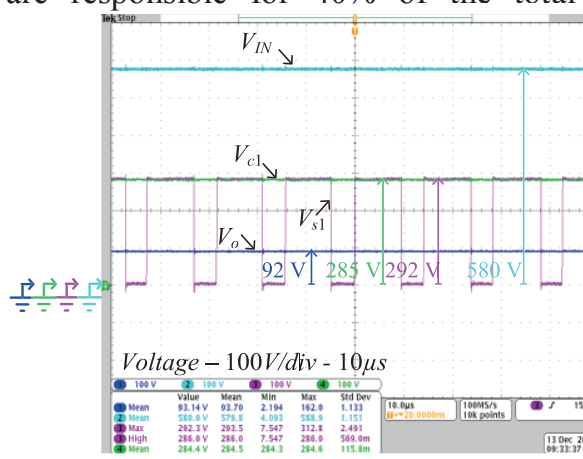

(a)

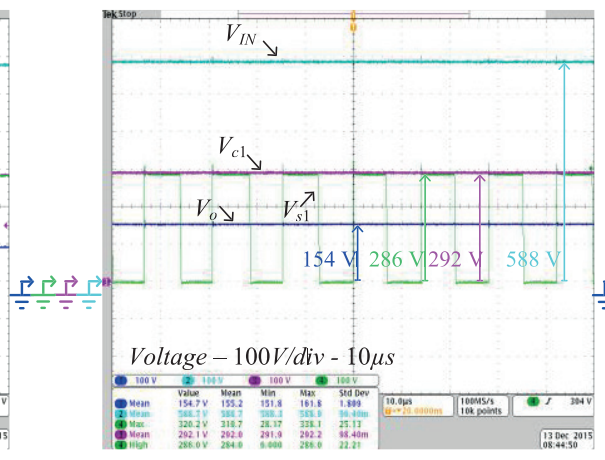

(b) topology presented the greater theoretical efficiency among the three studied structures $(98.77 \%)$. In the buck topology, the largest loss occurs in the diode and switches, of which $25 \%$ are commutation losses and $49 \%$ are conduction losses (theoretical values).

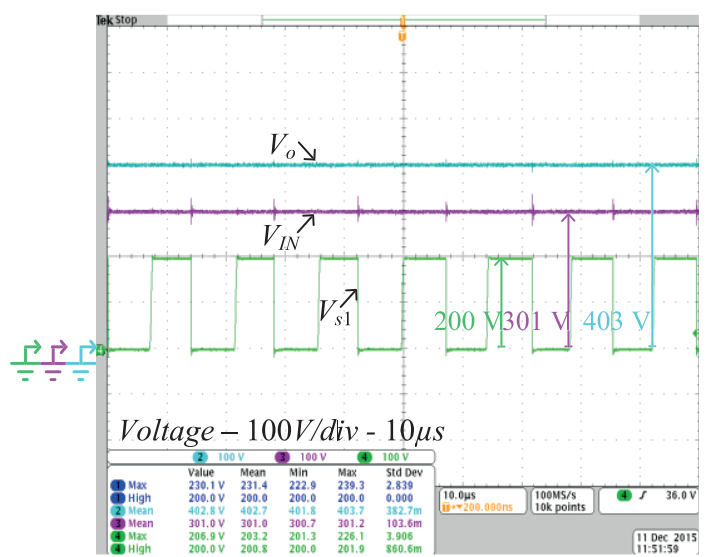

Fig. 10. Experimental results for the boost converter derived from the HACC: input voltage $\left(V_{i N}\right)$, output voltage $\left(V_{o}\right)$ and voltage stress on switch $S_{1}\left(V_{S 1}\right)$.

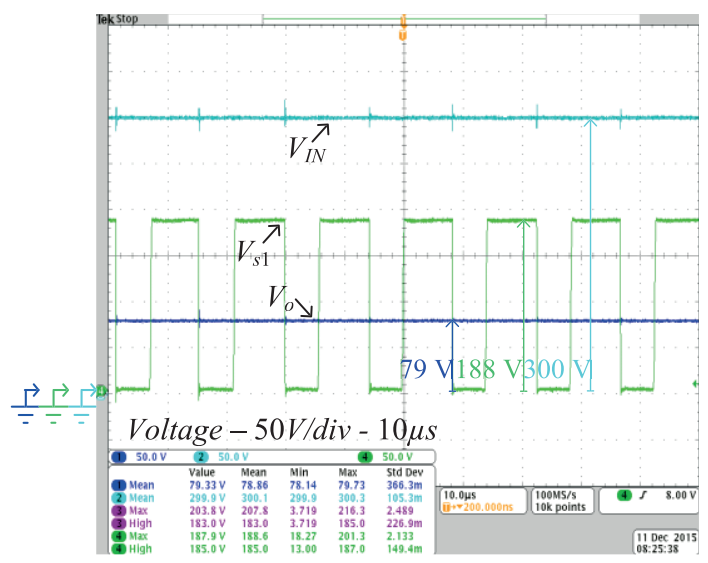

Fig. 11. Experimental results for the buck-boost converter derived from the HACC: input voltage $\left(V_{i N}\right)$, output voltage $\left(V_{o}\right)$ and voltage stress on switch $S_{1}\left(V_{S 1}\right)$.

Fig. 12. Experimental results for the buck converter derived from the HACC: input voltage $\left(V_{I N}\right)$, output voltage $\left(V_{o}\right)$, voltage stress on switch $S_{1}\left(V_{S 1}\right)$ and voltage stress on capacitor $C_{1}\left(V_{C 1}\right)$. (a) for $D=0.3$, (b) for $D=0.5$ and (c) for $D=0.7$. 


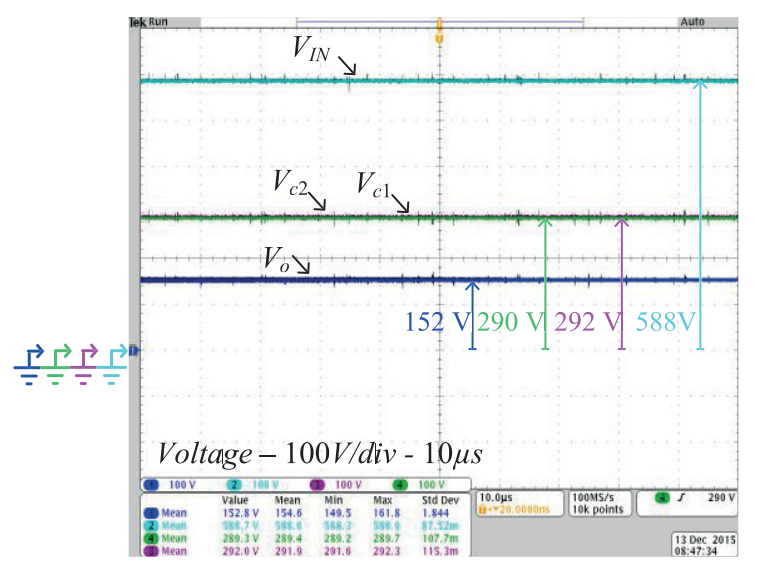

Fig. 13. Experimental results for the buck converter derived from the HACC: test to verify the self-balancing provided by the $\mathrm{SC}$ on capacitors $C_{1}$ and $C_{2}$

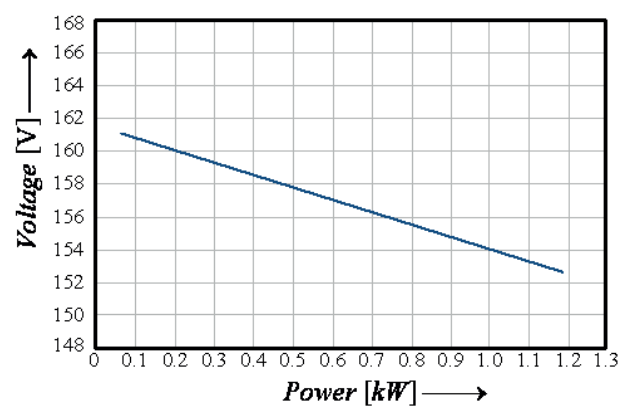

Fig. 14. Regulation of the converter for a duty cycle of $D=0.5$. Measurements for the entire power range.

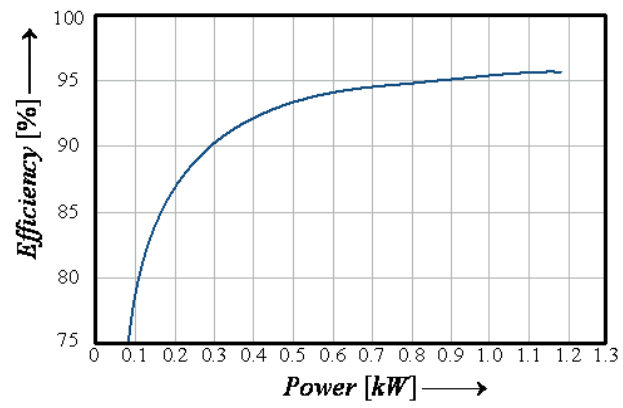

Fig. 15. Efficiency measurements for the buck converter derived from proposed HACC.

\section{CONCLUSIONS}

A new hybrid dc-dc commutation cell is proposed in this paper, which is obtained through the integration of the ASCC and the CCC. The hybrid cell can generate a new family composed by three converters: a hybrid buck, a hybrid boost and a hybrid buck-boost. By changing only the input and output connections, the step-up/step-down characteristic could be achieved from the commutation cell. A bidirectional structure can be obtained by substituting the power diode $D_{1}$ for an extra active switch, as proposed in [34].

The buck, boost and buck-boost topologies provide a high resolution of output voltage adjustment in relation to the duty cycle, since they have a small range of gain for a large range of duty cycles. This feature could be beneficial for certain applications, especially for high gain converters operating in closed loop. However, as a drawback, the limited gain reduces the applications of the converters, and also they have a higher number of components in comparison with conventional topologies. Hence, the converters proposed herein show good performance for application in systems that require either step-up or step-down conversion, higher accuracy between the static gain versus duty cycle, reduced voltage stress on the components, and rated power up to $700 \mathrm{~W}$. In addition, the notable features of the buck converter include the static gain, voltage stress, generalization and simplicity. These features make it suitable for high stepdown converters, in which a high rate of conversion is required (e.g., in auxiliary power supplies and DC-DC distribution systems).

The results of the theoretical studies were corroborated in tests with a $1 \mathrm{~kW}$ prototype, which was used for the experimental verification of the three topologies proposed herein. For the buck topology, an efficiency of 95\% was obtained at rated power. A comparison between the hybrid structures and conventional converters highlights the advantages and disadvantages of these structures in relation to the static gain, the voltage stress and the number of components.
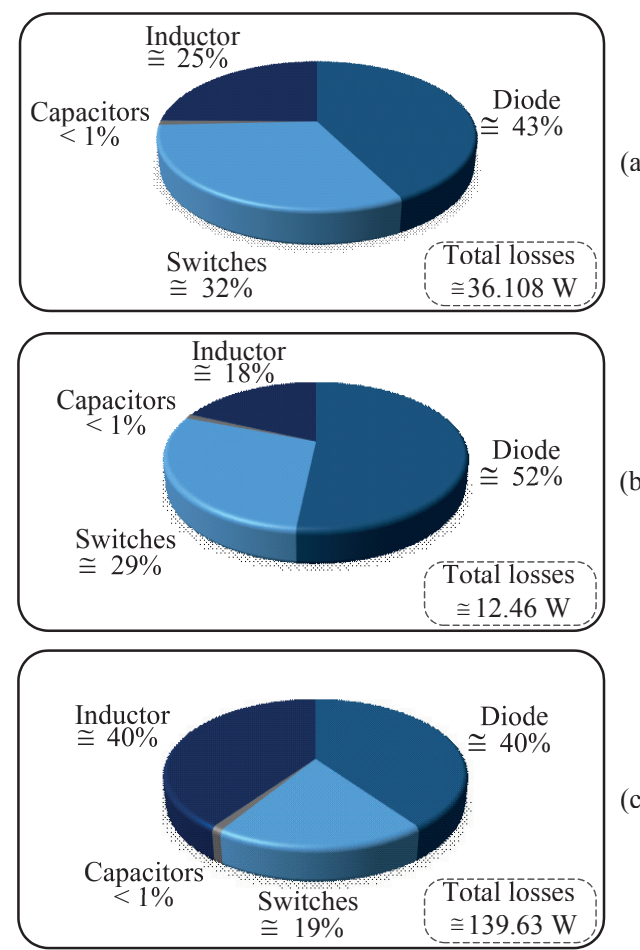

Fig. 16 -Theoretical distribution of losses at rated power (1kW): (a) buck topology, efficiency $\cong 96.51 \%$; (b) boost topology, efficiency $\cong 98.77 \%$ and $\quad$ (c) buck-boost topology, efficiency $\cong 87.74 \%$.

\section{REFERENCES}

[1] J. Wang, F. Z. Peng, J. Anderson, A. Joseph, and R. Buffenbarger, "Low cost fuel cell converter system for residential power generation," IEEE Transactions on Power Electronics, vol. 19, no. 5, p. 1315-1322, Sep. 2004.

[2] D. G. Bandeira, T. B. Lazzarin, and I. Barbi, "High Voltage Power Supply Using a T-Type Parallel Resonant DC-DC Converter," IEEE Transactions on Industry Applications, vol. 54, no. 3, p. 2459-2470, May 2018. 
[3] M. Forouzesh, Y. P. Siwakoti, S. A. Gorji, F. Blaabjerg, and B. Lehman, "Step-Up DC-DC Converters: A Comprehensive Review of Voltage-Boosting Techniques, Topologies, and Applications," IEEE Transactions on Power Electronics, vol. 32, no. 12, p. 9143-9178, Dec. 2017.

[4] B. R. Ananthapadmanabha, R. Maurya, and S. R. Arya, "Improved Power Quality Switched Inductor Cuk Converter for Battery Charging Application," IEEE Transactions on Power Electronics, p. 1-1, 2018.

[5] T. Yao, C. Nan, and R. Ayyanar, "A New SoftSwitching Topology for Switched Inductor High Gain Boost," IEEE Transactions on Industry Applications, vol. 54, no. 3, p. 2449-2458, May 2018.

[6] M. Chen, K. Li, J. Hu, and A. Ioinovici, "Generation of a Family of Very High DC Gain Power Electronics Circuits Based on Switched-Capacitor-Inductor Cells Starting from a Simple Graph," IEEE Transactions on Circuits and Systems I: Regular Papers, vol. 63, no. 12, p. 2381-2392, Dec. 2016.

[7] M. A. Salvador, T. B. Lazzarin, and R. F. Coelho, "High Step-Up DC-DC Converter With Active SwitchedInductor and Passive Switched-Capacitor Networks," IEEE Transactions on Industrial Electronics, vol. 65, no. 7, p. 5644-5654, Jul. 2018.

[8] B. Axelrod, Y. Berkovich, and A. Ioinovici, "SwitchedCapacitor/Switched-Inductor Structures for Getting Transformerless Hybrid DC-DC PWM Converters," IEEE Transactions on Circuits and Systems I: Regular Papers, vol. 55, no. 2, p. 687-696, Mar. 2008.

[9] O. Abutbul, A. Gherlitz, Y. Berkovich, and A. Ioinovici, "Step-up switching-mode converter with high voltage gain using a switched-capacitor circuit," IEEE Transactions on Circuits and Systems I: Fundamental Theory and Applications, vol. 50, no. 8, p. 1098-1102, Aug. 2003.

[10] M. Prudente, L. L. Pfitscher, G. Emmendoerfer, E. F. Romaneli, and R. Gules, "Voltage Multiplier Cells Applied to Non-Isolated DC-DC Converters," IEEE Transactions on Power Electronics, vol. 23, no. 2, p. 871-887, Mar. 2008.

[11] M. D. Vecchia, M. A. Salvador, and T. B. Lazzarin, "Hybrid Nonisolated DC-DC Converters Derived From a Passive Switched-Capacitor Cell," IEEE Transactions on Power Electronics, vol. 33, no. 4, p. 3157-3168, Apr. 2018.

[12] D. F. Cortez, G. Waltrich, J. Fraigneaud, H. Miranda, and I. Barbi, "DC-DC Converter for Dual-Voltage Automotive Systems Based on Bidirectional Hybrid Switched-Capacitor Architectures," IEEE Transactions on Industrial Electronics, vol. 62, no. 5, p. 3296-3304, May 2015.

[13] R. Stala, Z. Waradzyn, A. Penczek, A. Mondzik, and A. Skala, "A Switched-Capacitor DC-DC Converter with Variable Number of Voltage Gains and Fault-tolerant Operation," IEEE Transactions on Industrial Electronics, p. 1-1, 2018.

[14] M. K. Nguyen, T. D. Duong, and Y. C. Lim, "SwitchedCapacitor-Based Dual-Switch High-Boost DC-DC
Converter," IEEE Transactions on Power Electronics, vol. 33, no. 5, p. 4181-4189, May 2018.

[15] Z. Chen, Q. Zhou, and J. Xu, "Coupled-inductor boost integrated flyback converter with high-voltage gain and ripple-free input current," IET Power Electronics, vol. 8, no. 2, p. 213-220, 2015.

[16] X. Hu, J. Wang, L. Li, and Y. Li, “A Three-Winding Coupled-Inductor DC-DC Converter Topology With High Voltage Gain and Reduced Switch Stress," IEEE Transactions on Power Electronics, vol. 33, no. 2, p. 1453-1462, Feb. 2018.

[17] M. M. Haji-Esmaeili, E. Babaei, and M. Sabahi, "High Step-Up Quasi-Z Source DC-DC Converter," IEEE Transactions on Power Electronics, p. 1-1, 2018.

[18] H. Shen, B. Zhang, and D. Qiu, "Hybrid Z-Source Boost DC-DC Converters," IEEE Transactions on Industrial Electronics, vol. 64, no. 1, p. 310-319, Jan. 2017.

[19] D. Sha, Z. Guo, and X. Liao, "Cross-Feedback OutputCurrent-Sharing Control for Input-Series-OutputParallel Modular DC-DC Converters," IEEE Transactions on Power Electronics, vol. 25, no. 11, p. 2762-2771, Nov. 2010.

[20] D. Sha, K. Deng, and X. Liao, "Duty Cycle Exchanging Control for Input-Series-Output-Series Connected Two PS-FB DC-DC Converters," IEEE Transactions on Power Electronics, vol. 27, no. 3, p. 1490-1501, Mar. 2012.

[21] M. Kasper, D. Bortis, and J. W. Kolar, "Novel High Voltage Conversion Ratio 'Rainstick' DC/DC Converters," in 2013 IEEE Energy Conversion Congress and Exposition, 2013, p. 789-796.

[22] M. T. V and I. Barbi, "Nonisolated high step-up stacked dc-dc converter based on boost converter elements for high power application," in 2011 IEEE International Symposium of Circuits and Systems (ISCAS), p. 249252. 2011

[23] G. Chen et al., "Topology Derivation and Analysis of Integrated Multiple Output Isolated DC-DC Converters With Stacked Configuration for Low-Cost Applications," IEEE Transactions on Circuits and Systems I: Regular Papers, vol. 64, no. 8, p. 2207-2218, Aug. 2017.

[24] M. D. Vecchia, T. B. Lazzarin, I. Barbi. "Estudo de conversores estáticos CA-CA monofásicos e trifásicos baseados no princípio do capacitor chaveado," Eletrônica de Potência, vol. 20, no. 2, p. 160-171, May 2016.

[25] J. C. Rosas-Caro, J. M. Ramirez, F. Z. Peng, and A. Valderrabano, "A DC-DC multilevel boost converter," IET Power Electronics, vol. 3, no. 1, p. 129-137, Jan. 2010.

[26] K. Yao, Y. Qiu, M. Xu, and F. C. Lee, "A novel winding-coupled buck converter for high-frequency, high-step-down DC-DC conversion," IEEE Transactions on Power Electronics, vol. 20, no. 5, p. 1017-1024, Sep. 2005.

[27] F. Zhang, L. Du, F. Z. Peng, and Z. Qian, “A New Design Method for High-Power High-Efficiency Switched-Capacitor DC-DC Converters," IEEE 
Transactions on Power Electronics, vol. 22, no. 3, p. 832-840, Sept. 2017.

[28] G. V. Silva, R. F. Coelho, T. B. Lazzarin, "Modelagem do conversor boost com células a capacitor chaveado por meio de um conversor equivalente de ordem reduzida," Eletrônica de Potência, vol. 22, no. 3, p. 288-297, Spt. 2017.

[29] J. M. de Andrade, G. V. Silva, R. F. Coelho, T. B. Lazzarin, "Inversor boost a capacitor chaveado conectado à rede elétrica," Eletrônica de Potência, vol. 23, no. 4, p. 466-476, Dec. 2018.

[30] N. C. D. Pont, G. Waltrich, T. B. Lazzarin, "Transformerless step-up inverter based on switchedcapacitor converter technology," Eletrônica de Potência, vol. 22, no. 3, p. 269-278, Sept.. 2017.

[31] M. D. Vecchia and T. B. Lazzarin, "Hybrid DC-DC buck converter with active switched capacitor cell and low voltage gain," in 2016 IEEE Energy Conversion Congress and Exposition (ECCE), 2016, p. 1-6.

[32] T. Tong, S. K. Lee, X. Zhang, D. Brooks, and G. Y. Wei, "A Fully Integrated Reconfigurable SwitchedCapacitor DC-DC Converter With Four Stacked Output Channels for Voltage Stacking Applications," IEEE Journal of Solid-State Circuits, vol. 51, no. 9, p. 2142 2152, Sep. 2016.

[33] R. L. Silva, T. B. Lazzarin, and I. Barbi, "Reduced Switch Count Step-Up/Step-Down Switched-Capacitor Three-Phase AC-AC Converter," IEEE Transactions on Industrial Electronics, vol. 65, p. 8422-8432, 2018.

[34] D. Flores Cortez, G. Waltrich, J. Fraigneaud, H. Miranda and I. Barbi, "DC-DC Converter for DualVoltage Automotive Systems Based on Bidirectional Hybrid Switched-Capacitor Architectures," in IEEE Transactions on Industrial Electronics, vol. 62, no. 5, p. 3296-3304, May 2015.

\section{BIOGRAPHIES}

Mauricio Dalla Vecchia was born in Francisco Beltrão, Parana State, Brazil, in 1990. He received the B.Sc. and M. Sc. degrees in Electrical Engineering from the Federal University of Santa Catarina (UFSC), Florianopolis, Brazil, in 2014 and 2016, respectively.

$\mathrm{He}$ is currently pursuing the Ph.D. degree in Electrical Engineering at KU Leuven (EnergyVille), Leuven (Genk), Belgium.

His interests include direct ac-ac power converters, switched-capacitor converters, hybrid dc-dc switchedcapacitor converters, wide band-gap materials.

Jessika Melo de Andrade was born in Florianopolis, Brazil, in July 1994, graduated in Electronic Systems at the Federal Institute of Santa Catarina (IFSC), Florianopolis, in 2015. She received a Master's degree in Electrical Engineering from the Federal University of Santa Catarina (UFSC), Florianopolis, 2018.

She is currently a doctoral student in Electrical Engineering at Power Electronics Institute at the UFSC.

Her interests include modeling and control applied to power electronics, converters / inverters with gain cells. Msc. Andrade is a member of SOBRAEP.
Neilor C. Dal Pont was born in Criciúma, Santa Catarina, Brazil, in 1989. He received the B.Sc. and M.Sc degree in Electrical Engineering from the Federal University of Santa Catarina (UFSC), Florianopolis, Brazil, in 2015 and 2017, respectively.

He is currently working towards the Ph.D. degree at the Department of Electrical and Electronic Engineering (EEL) from UFSC, at the Power Electronics Institute (INEP).

His interests include switched-capacitor converters, inverters, high-voltage dc-dc converters, resonant converters.

André Luis Kirsten was born in Santa Maria, Brazil, in 1986. He received the B.S, M.Sc., and Ph.D. degrees from the Federal University of Santa Maria, in 2009, 2011, and 2014, respectively, all in Electrical Engineering.

He is currently a full professor at the Federal University of Santa Catarina.

His main research interests are power electronics, switching-mode power converters design, power factor correction, and solid-state transformers.

Telles Brunelli Lazzarin was born in Criciuma, Santa Catarina State, Brazil, in 1979. He received the B.Sc., M.Sc. and $\mathrm{Ph} . \mathrm{D}$. degrees in Electrical Engineering from the Federal University of Santa Catarina (UFSC), Florianopolis, Brazil, in 2004, 2006 and 2010, respectively.

He is currently a Full Professor with the Department of Electronic and Electrical Engineering (EEL) at the UFSC.

His interests include switched-capacitor converters, inverters, rectifiers, high-voltage and high-gain dc-dc converters. Dr. Lazzarin is a member of the following societies: SOBRAEP, PELS, IAS and IES. 